\title{
Article \\ Controlling Conditions of the One-Dimensional Consolidation Test on Peat Soil
}

\author{
Bo Peng ${ }^{1, *}$, Ruiling Feng ${ }^{1}$, Lijian $\mathrm{Wu}^{2}$ and Yupeng Shen ${ }^{1}$ \\ 1 School of Civil Engineering, Beijing Jiaotong University, No. 3 Shangyuancun, Haidian District, \\ Beijing 100044, China; rlfeng@bjtu.edu.cn (R.F.); ypshen@bjtu.edu.cn (Y.S.) \\ 2 Research Institute of Highway, Ministry of Transport, No. 8 West Tucheng Rd., Haidian District, \\ Beijing 100088, China; lj.wu@rioh.cn \\ * Correspondence: 19115064@bjtu.edu.cn
}

check for updates

Citation: Peng, B.; Feng, R.; Wu, L.; Shen, Y. Controlling Conditions of the One-Dimensional Consolidation Test on Peat Soil. Appl. Sci. 2021, 11, 11125 https://doi.org/10.3390/

app112311125

Academic Editors: Tongmin Sa and Claudio De Pasquale

Received: 27 September 2021

Accepted: 18 November 2021

Published: 24 November 2021

Publisher's Note: MDPI stays neutral with regard to jurisdictional claims in published maps and institutional affiliations.

Copyright: (c) 2021 by the authors. Licensee MDPI, Basel, Switzerland This article is an open access article distributed under the terms and conditions of the Creative Commons Attribution (CC BY) license (https:/ / creativecommons.org/licenses/by/ $4.0 /$ )

\begin{abstract}
This paper studies the changes in the loss on ignition (LOI), total nitrogen content (TN), and strain in a one-dimensional consolidation test on peat soil. The effects of small-range fluctuations in the ambient temperature and changes in the sample height on the consolidation process of peat soil are proposed and verify the inhibitory effect of thymol on the decomposition of organic matter. The results show that when the ambient temperature fluctuates in a small range, the consolidation rate is significantly affected. Under a low load, the ambient temperature increases by $1-2{ }^{\circ} \mathrm{C}$, and the consolidation rate can be increased by up to 10 times. This study presents the changes in loss on ignition (LOI) and total nitrogen content (TN) during consolidation, which proves that soaking the samples with a thymol solution can effectively control the decomposition of organic matter in peat soil. The strain of peat soil at a height of $30 \mathrm{~mm}$ is greater than or equal to that of other height samples, while that of mucky soil is $20 \mathrm{~mm}$. Therefore, $30 \mathrm{~mm}$ is the recommended sample height for peat soil for the one-dimensional consolidation test.
\end{abstract}

Keywords: peat soil; one-dimensional consolidation test; control conditions; total nitrogen content; thymol

\section{Introduction}

Peat soil is a loose, water-rich accumulation that us formed from organic matter that has been deposited in swamp lakes after plant death [1] and accounts for $~ 5-8 \%$ of the total area of the Earth [2]. In China, $64 \%$ of peat is distributed in the Sichuan, Anhui, Heilongjiang, and Yunnan provinces [3]. The content of organic matter in peat soil is generally more than $10 \%$, with some having an organic matter content as high as $98 \%$. According to the Code for Investigation of Geotechnical Engineering (GB 50021-2001) [4], soil with an organic matter content of more than $60 \%$ is peat, and soil with an organic matter content that is more than $10 \%$ and less than or equal to $60 \%$ is peaty soil. According to the organic matter content $\left(W_{u}\right)$, peaty soil can be further divided into low organic peaty soil $(10 \%<W u \leq 25 \%)$, medium organic peaty soil $(25 \%<W u \leq 40 \%)$, and highly organic peaty soil $(40 \%<W u \leq 60 \%)$. Peat soil features a high water content, a large pore ratio, high compressibility, low strength, strong rheology, and compressibility that is 5-20 times higher than that of common soft clay $[5,6]$. A peat soil foundation can encounter several problems, such as a large amount of settlement and long settlement times [7]. For example, an embankment on a peat soil foundation in Canada has more than $7 \mathrm{~m}$ of settlement [8]. A highway in Miyazaki County, Japan, that is built on a foundation with a peat soil layer has more than $11 \mathrm{~m}$, of settlement, as measured over four years [9]. After five years of operation, the accumulated settlement of the peat soil foundation under an expressway in Yunnan Province is $1.3 \mathrm{~m}$, and settlement is still rapidly developing.

Because of the long settlement time and large deformations that can occur to peat soil foundations, researchers have studied the consolidation characteristics of peat soil [10-12]. 
Whiles studying this process, it was found that temperature [13,14], stress conditions, and the over consolidation ratio influence the consolidation characteristics of peat soil $[15,16]$.

Hanson et al. [17] studied the deformation difference of peat soil in the range of $15-65{ }^{\circ} \mathrm{C}$ for every temperature increase of $10^{\circ} \mathrm{C}$. The results show that the consolidation deformation of peat soil increases when the temperature increases. Fox and Edil (1996) compared the results of consolidation tests that were conducted at $24{ }^{\circ} \mathrm{C}$ and $35^{\circ} \mathrm{C}$ and observed that the secondary consolidation coefficient of peat soil has a positive correlation with the temperature during testing. The creep temperature coefficient was first proposed by Fox and has shown to be able to modify the secondary consolidation coefficient. Mesri et al. [13], Madaschi and Gajo [14], and Dhowian and Edil [18] considered the results and conclusions from previous studies of the effect of temperature on the consolidation characteristics of peat soil, so the ambient temperature is controlled at about $20{ }^{\circ} \mathrm{C}$ in their research.

Due to the rich organic matter in peat soil, microorganisms propagate rapidly, and biological oxidation (mainly including humification and mineralization) occurs in an oxygen rich environment, which leads to changes in the soil structure and properties [19]. Prokopovich [20] studied two peatlands in California and Florida and suggested that $80 \%$ of the subsidence in peatlands in a hot and humid climate is due to the biological oxidation of aerobic bacteria. Laiho [21] analyzed the carbon pool level of peatland, and Philben et al. [22] analyzed the change process of amino acids in peatland, which proved that the contact between peatland and air accelerated the decomposition of the organic matter that was present in the peat soil. Mesri et al. [13] found that the decomposition of peat soil is accelerated when it is consolidated in air and proposed that a $1 \%$ thymol solution should be used to control the decomposition of organic matter during consolidation tests. Klari et al. [23] demonstrated that thymol can effectively control bacterial reproduction.

Previous studies have found that the height of peat samples can also affect the consolidation characteristics and the reliability of test data [24]. Long and Boylan [25] compared the consolidation process of specimens with heights of $20 \mathrm{~mm}$ and $50 \mathrm{~mm}$ under the load of $20 \mathrm{kPa}$ and $80 \mathrm{kPa}$ and found that the primary consolidation time of a $50 \mathrm{~mm}$ specimen is longer under the load of $20 \mathrm{kPa}$, with negligible differences being found under the load of $80 \mathrm{kPa}$. The use of a specimen that is $50 \mathrm{~mm}$ in height is recommended to complete consolidation tests. Carlsten [26] studied Swedish peat samples with a height of $45 \mathrm{~mm}$, while Janbu conducted one-dimensional consolidation tests on peat samples with a height of $50 \mathrm{~mm}$. Lefebvre et al. [27] studied Canadian peat soils using specimens that were $38 \mathrm{~mm}$ in height.

Some researchers have suggested that a new method should be developed to study the compressibility of peat soil [28]. Previously, temperature, bio-oxidation, and sample height, which need to be controlled in experiments, had been shown to influence the consolidation behavior of peat soil. In current studies on the influence of temperature, the minimum temperature gradient is $10^{\circ} \mathrm{C}$, but small temperature fluctuations may affect the peat soil consolidation process. We also need test the controlling effect of a thymol solution on biological oxidation. Researchers have not yet come to a unified conclusion on how to select the most appropriate sample height, which is worthy of further study.

\section{Materials and Methods}

In China, herbaceous peat is the main type of peat and demonstrates the characteristics of weak acidity $(\mathrm{pH}=5-6)$, a high humic acid content, and a medium $\mathrm{N}$ content [8]. Figure 1 shows the organic carbon reserves of peatlands in all of the provinces in China. The peat reserves in Yunnan exceed 100 million tons, amount that is only lower to that of Sichuan Province. Undisturbed soil samples were obtained in Eryuan County, Dali City, Yunnan Province, China. The retrieved undisturbed soil was packed in sampling barrels, wrapped with plastic film, and then placed in a constant temperature and humidity curing box in the laboratory. 


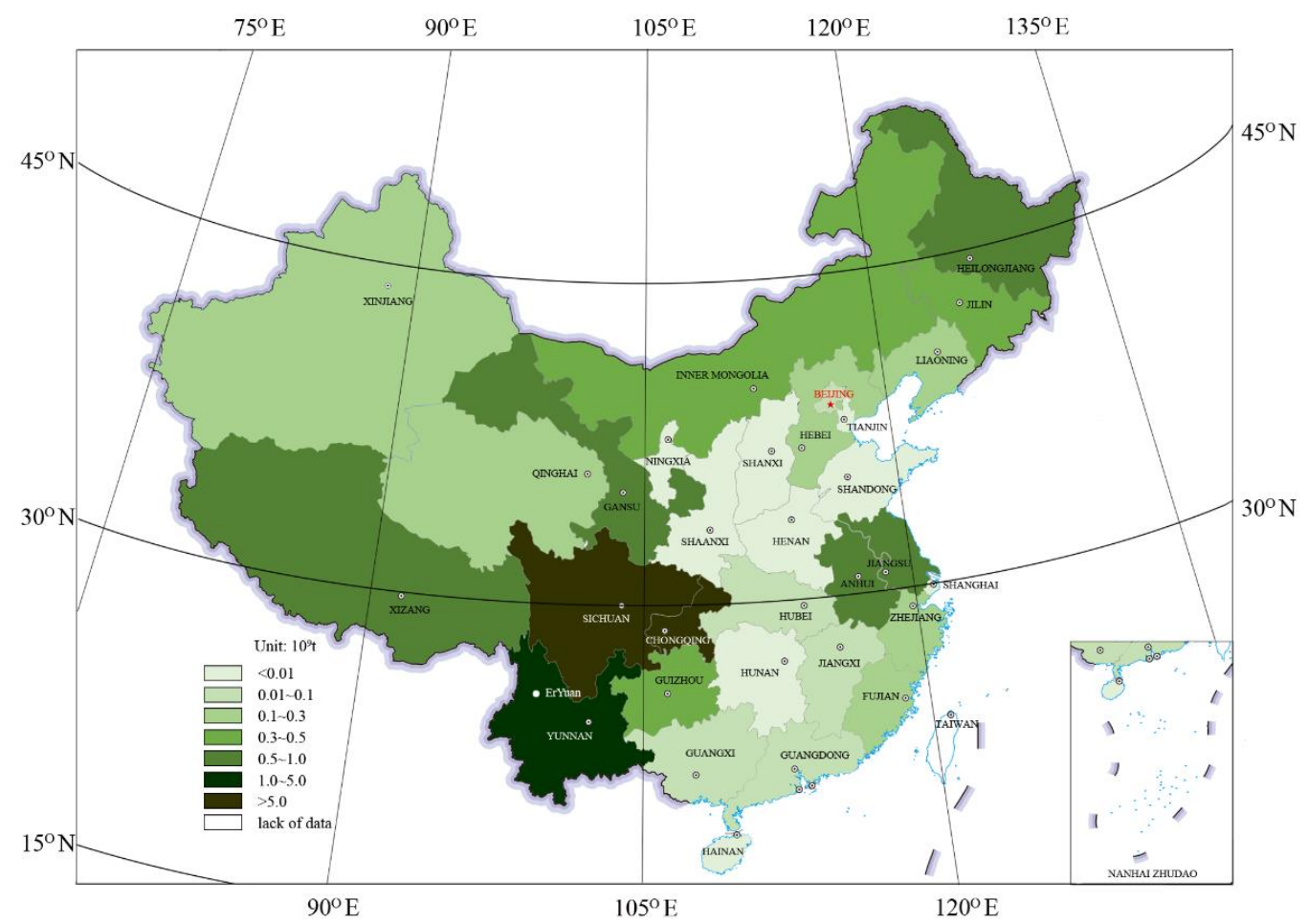

Figure 1. Organic carbon reserves of peatland in provinces, cities, and autonomous regions of China.

The sampling location in Eryuan County was at $26^{\circ} 7^{\prime} 18^{\prime \prime} \mathrm{N}$ and $99^{\circ} 58^{\prime} 14^{\prime \prime} \mathrm{E}$ and at an altitude of $2060 \mathrm{~m}$. The thin-walled soil sampler was used for drilling and sampling. The in situ temperature of the peat was measured by a JDC-2 geothermometer produced by China Shanglong Electric (Shanghai), which showed the temperature to be $20^{\circ} \mathrm{C}$.

The stratum information from top to bottom is as follows:

(1) Sand (from $0 \mathrm{~m}$ to $3.3 \mathrm{~m}$ );

(2) Clay (from $3.3 \mathrm{~m}$ to $5.1 \mathrm{~m}$ );

(3) Peat (from $5.0 \mathrm{~m}$ to $5.3 \mathrm{~m}$ );

(4) Clay (from $5.3 \mathrm{~m}$ to $8.9 \mathrm{~m}$ );

(5) Peat (from $8.9 \mathrm{~m}$ to $9.6 \mathrm{~m}$ ).

The sampling location in West Lake was at $26^{\circ} 0^{\prime} 55^{\prime \prime} \mathrm{N}$ and $100^{\circ} 3^{\prime} 12^{\prime \prime} \mathrm{E}$ and was at an altitude of $1970 \mathrm{~m}$, near the bank of West Lake. There was a large amount of peat soil at $\sim 1 \mathrm{~m}$ underground. The undisturbed soil was obtained by manual excavation, and the in situ temperature of the peat soil was measured using a geothermometer, which determined that the in situ temperature was $23^{\circ} \mathrm{C}$. A previous study obtained a temperature of $21^{\circ} \mathrm{C}$ at $1 \mathrm{~m}$ underground in Dali in June [29], which is similar to the data measured in this study. Table 1 shows the physical and mechanical properties of the soil samples.

This paper analyzes the effects of ambient temperature, thymol solution, and sample height on the consolidation characteristics of peat soil with a single-lever consolidation apparatus produced by China Nanjing Soil Instrument (Nanjing, Jiangsu). The diameter of the ring cutter sample was $61.8 \mathrm{~mm}$, and the height was $20 \mathrm{~mm}$ for most tests, except for the analysis determining the influence of the sample height. The applied load ranged from 12.5 to $800 \mathrm{kPa}$, and a loading ratio of one was determined. Due to the long duration of the secondary consolidation process in peat soil, deformation of less than $0.05 \mathrm{~mm} /$ day [30] or $0.02 \mathrm{~mm} /$ day [31] is regarded as the condition marking the end of the test in some studies. In this study, two types of criteria were used to denote the end of the test and to determine different test purposes. One was a 24-hour loading period, as specified in the Test Methods of Soils for Highway Engineering (JTG 3430-2020) [32]; under these conditions, the deformation should less than $0.01 \mathrm{~mm}$ in the last hour. The other criterion 
indicates that deformation should be less than $0.01 \mathrm{~mm} /$ day to analyze the creep process of peat soil consolidation. Table 2 lists the specific test scheme and loading sequence.

Laboratory tests were conducted according to the JTG 3430-2020 [32]. The moisture content was measured by drying, and the oven temperature was set to $65^{\circ} \mathrm{C}$ because the organic matter content was higher than $5 \%$.

The concentration of the thymol solution was 1\%, as recommended by Mesri et al. [13]. There are two ways to use thymol solution:

(1) The first way is to spray a small amount of the thymol solution on the upper and lower surface of the soil sample and to wet the filter paper. During the test, a cotton cloth is covered with solution to maintain the moisture level.

(2) The second way is to quickly pour the thymol solution into the consolidation box and to immerse the sample after the first load is added.

Table 1. Physical and mechanical properties.

\begin{tabular}{|c|c|c|c|c|c|c|c|c|}
\hline Purpose & Specimen & Organic Matter Content & Location & $\begin{array}{l}\text { LOI } \\
(\%)\end{array}$ & $\begin{array}{l}\text { Specific } \\
\text { Gravity }\end{array}$ & $\begin{array}{l}\text { Density } \\
\left(\mathrm{g} / \mathrm{cm}^{3}\right)\end{array}$ & $\begin{array}{c}\text { Moisture } \\
\text { Content (\%) }\end{array}$ & $\begin{array}{c}\text { Saturation } \\
(\%)\end{array}$ \\
\hline \multirow{4}{*}{$\begin{array}{l}\text { Effect of test } \\
\text { temperature }\end{array}$} & $\mathrm{T}_{1}$ & Highly organic peaty soil & \multirow{4}{*}{$\begin{array}{l}\text { West Lake, } \\
\text { Dali }\end{array}$} & 58.8 & 1.98 & 1.09 & 217.14 & 90.32 \\
\hline & $\mathrm{T}_{2}$ & Low organic peaty soil & & 21.4 & 2.20 & 1.49 & 62.36 & 98.7 \\
\hline & $\mathrm{T}_{3}$ & Highly organic peaty soil & & 48.8 & 1.93 & 1.25 & 140.94 & 98.21 \\
\hline & $\mathrm{T}_{4}$ & Low organic peaty soil & & 32.1 & 1.89 & 1.25 & 162.05 & 99.57 \\
\hline \multirow{17}{*}{$\begin{array}{c}\text { Effect of } \\
\text { thymol } \\
\text { (S stands for } \\
\text { use method } \\
\text { (1) J stands } \\
\text { for use } \\
\text { method (2) }\end{array}$} & $\mathrm{S}_{1}$ & Highly organic peaty soil & \multirow{15}{*}{$\begin{array}{c}\text { West Lake, } \\
\text { Dali }\end{array}$} & 42.6 & 1.9 & 1.27 & 167.31 & 98.52 \\
\hline & $\mathrm{S}_{2}$ & Highly organic peaty soil & & 41.8 & 1.98 & 0.92 & 177.15 & 72.04 \\
\hline & $\mathrm{S}_{3}$ & Highly organic peaty soil & & 40.2 & 1.9 & 1.23 & 175.15 & 98.44 \\
\hline & $\mathrm{S}_{4}$ & Medium organic peaty soil & & 33.0 & 1.9 & 1.31 & 96.17 & 92.85 \\
\hline & $\mathrm{S}_{5}$ & Highly organic peaty soil & & 41.1 & 1.89 & 1.25 & 162.05 & 99.57 \\
\hline & $\mathrm{S}_{6}$ & Medium organic peaty soil & & 33.1 & 1.89 & 1.3 & 117.98 & 98.61 \\
\hline & $\mathrm{S}_{7}$ & Highly organic peaty soil & & 48.8 & 1.93 & 1.25 & 140.94 & 98.21 \\
\hline & $\mathrm{S}_{8}$ & Peat & & 61.6 & 1.93 & 1.21 & 175.74 & 98.37 \\
\hline & $\mathrm{J}_{1}$ & Highly organic peaty soil & & 41.2 & \multirow{3}{*}{1.94} & 1.08 & 362.75 & 95.82 \\
\hline & $\mathrm{J}_{2}$ & Highly organic peaty soil & & 44.1 & & 1.03 & 269.70 & 87.31 \\
\hline & $\mathrm{J}_{3}$ & Highly organic peaty soil & & 59.2 & & 1.28 & 128.50 & 98.04 \\
\hline & $\mathrm{J}_{4}$ & Highly organic peaty soil & & 55.8 & \multirow{4}{*}{1.87} & 1.29 & 109.48 & 94.69 \\
\hline & $\mathrm{J}_{5}$ & Highly organic peaty soil & & 50.3 & & 1.23 & 114.16 & 89.75 \\
\hline & $\mathrm{J}_{6}$ & Highly organic peaty soil & & 47.0 & & 1.29 & 119.50 & 97.22 \\
\hline & $\mathrm{J}_{7}$ & Highly organic peaty soil & & 43.8 & & 1.31 & 117.51 & 97.23 \\
\hline & $\mathrm{S}_{9}$ & Peat & \multirow{2}{*}{ Eryuan, Dali } & 66.5 & \multirow{2}{*}{2.08} & 1.09 & 251.06 & 91.56 \\
\hline & $\mathrm{S}_{10}$ & Highly organic peaty soil & & 55.8 & & 1.14 & 222.25 & 95.14 \\
\hline \multirow{5}{*}{$\begin{array}{c}\text { Effect of } \\
\text { specimen } \\
\text { height }\end{array}$} & $\mathrm{H}_{1}$ & Mucky soil & $\begin{array}{c}\text { West Lake, } \\
\text { Dali }\end{array}$ & 5.4 & 2.18 & 1.71 & 51.21 & \multirow{5}{*}{-} \\
\hline & $\mathrm{H}_{2}$ & Low organic peaty soil & Eryuan, Dali & 20.8 & 2.08 & 1.388 & 103.26 & \\
\hline & $\mathrm{H}_{3}$ & Medium organic peaty soil & \multirow{3}{*}{$\begin{array}{c}\text { West Lake, } \\
\text { Dali }\end{array}$} & 34.7 & 2.01 & 1.18 & 203.54 & \\
\hline & $\mathrm{H}_{4}$ & Highly organic peaty soil & & 56 & 1.93 & 1.04 & 338.25 & \\
\hline & $\mathrm{H}_{5}$ & Peat & & 75.2 & 1.87 & 0.92 & 590.8 & \\
\hline
\end{tabular}

Table 2. Test plan and loading sequence.

\begin{tabular}{|c|c|c|c|c|c|c|}
\hline Purpose & Specimen & $\begin{array}{c}\text { Height } \\
(\mathrm{mm})\end{array}$ & $\begin{array}{c}\text { Ambient } \\
\text { Temperature } \\
\left({ }^{\circ} \mathrm{C}\right)\end{array}$ & $\begin{array}{c}\text { Thymol } \\
\text { Concentration } \\
(\%)\end{array}$ & Load Level (kPa) and Loading Time & $\begin{array}{l}\text { Total Time } \\
\text { (d) }\end{array}$ \\
\hline \multirow{4}{*}{$\begin{array}{l}\text { Effect of test } \\
\text { temperature }\end{array}$} & $\mathrm{T}_{1}$ & \multirow{4}{*}{20} & \multirow{4}{*}{ Uncontrolled } & \multirow{4}{*}{0} & 12.5-25 (79 h per level) & 6.5 \\
\hline & $\mathrm{T}_{2}$ & & & & $12.5-25$ (79 h per level) & 6.5 \\
\hline & $\mathrm{T}_{3}$ & & & & $\begin{array}{c}12.5(24 \mathrm{~h})-25(24 \mathrm{~h})-50(24 \mathrm{~h})-100 \text { (24 h)-200 } \\
(24 \mathrm{~h})-400(24 \mathrm{~h})-800(53 \mathrm{~h})\end{array}$ & 8.2 \\
\hline & $\mathrm{T}_{4}$ & & & & $\begin{array}{c}12.5(24 \mathrm{~h})-25(24 \mathrm{~h})-50(24 \mathrm{~h})-100(24 \mathrm{~h})-200 \\
(24 \mathrm{~h})-400(24 \mathrm{~h})-800(53 \mathrm{~h})\end{array}$ & 8.2 \\
\hline
\end{tabular}


Table 2. Cont.

\begin{tabular}{|c|c|c|c|c|c|c|}
\hline Purpose & Specimen & $\begin{array}{l}\text { Height } \\
(\mathrm{mm})\end{array}$ & $\begin{array}{c}\text { Ambient } \\
\text { Temperature } \\
\left({ }^{\circ} \mathrm{C}\right)\end{array}$ & $\begin{array}{c}\text { Thymol } \\
\text { Concentration } \\
(\%)\end{array}$ & Load Level (kPa) and Loading Time & $\begin{array}{l}\text { Total Time } \\
\text { (d) }\end{array}$ \\
\hline \multirow{17}{*}{$\begin{array}{l}\text { Effect of } \\
\text { thymol }\end{array}$} & $\mathrm{S}_{1}$ & \multirow{15}{*}{20} & \multirow{15}{*}{23} & 0 & $12.5-25-50-100-200-400-800$ (24 h per level) & 7 \\
\hline & $\mathrm{S}_{2}$ & & & 0 & $12.5-25-50-100-200-400-800$ ( $24 \mathrm{~h}$ per level) & 7 \\
\hline & $\mathrm{S}_{3}$ & & & 1 & $12.5-25-50-100-200-400-800$ ( $24 \mathrm{~h}$ per level) & 7 \\
\hline & $\mathrm{S}_{4}$ & & & 1 & $12.5-25-50-100-200-400-800$ ( $24 \mathrm{~h}$ per level) & 7 \\
\hline & $\mathrm{S}_{5}$ & & & 0 & $12.5-25-50-100-200-400-800$ ( $24 \mathrm{~h}$ per level) & 7 \\
\hline & $\mathrm{S}_{6}$ & & & 0 & $\begin{array}{c}12.5(24 \text { h)-25 (24 h)-50 (24 h)-100 (24 h)-200 } \\
(24 \text { h)-400 (24 h)-800 (53 d) }\end{array}$ & 59 \\
\hline & $\mathrm{S}_{7}$ & & & 1 & $\begin{array}{c}12.5(24 \text { h)-25 (24 h)-50 (24 h)-100 (24 h)-200 } \\
(24 \text { h)-400 (24 h)-800 (53 d) }\end{array}$ & 59 \\
\hline & $\mathrm{S}_{8}$ & & & 1 & $12.5-25-50-100-200-400-800$ ( $24 \mathrm{~h}$ per level) & 7 \\
\hline & $\mathrm{J}_{1}$ & & & 0 & $\begin{array}{c}12.5(24 \mathrm{~h})-25(24 \mathrm{~h})-50(24 \mathrm{~h})-100(24 \mathrm{~h})-200 \\
(24 \mathrm{~h})-400(24 \mathrm{~h})-800(53 \mathrm{~d})\end{array}$ & 59 \\
\hline & $\mathrm{J}_{2}$ & & & 1 & $\begin{array}{c}12.5(24 \mathrm{~h})-25(24 \mathrm{~h})-50(24 \mathrm{~h})-100 \text { (24 h)-200 } \\
(24 \mathrm{~h})-400(24 \mathrm{~h})-800(53 \mathrm{~d})\end{array}$ & 59 \\
\hline & $\mathrm{J}_{3}$ & & & 1 & $\begin{array}{c}12.5(3 \mathrm{~d})-25(5 \mathrm{~d})-50(6 \mathrm{~d})-100(11 \mathrm{~d})-200 \\
(10 \mathrm{~d})-400(16 \mathrm{~d})-800(13 \mathrm{~d})\end{array}$ & 63 \\
\hline & $\mathrm{J}_{4}$ & & & 1 & $\begin{array}{l}12.5(3 \mathrm{~d})-25(5 \mathrm{~d})-50(6 \mathrm{~d})-100(11 \mathrm{~d})-200 \\
(10 \mathrm{~d})-400(16 \mathrm{~d})-800(13 \mathrm{~d})\end{array}$ & 63 \\
\hline & $\mathrm{J}_{5}$ & & & 1 & $\begin{array}{l}12.5(3 \mathrm{~d})-25(5 \mathrm{~d})-50(6 \mathrm{~d})-100(11 \mathrm{~d})-200 \\
(10 \mathrm{~d})-400(15 \mathrm{~d})-800(13 \mathrm{~d})\end{array}$ & 62 \\
\hline & $\mathrm{J}_{6}$ & & & 1 & $\begin{array}{l}12.5(3 \mathrm{~d})-25(5 \mathrm{~d})-50(6 \mathrm{~d})-100(11 \mathrm{~d})-200 \\
(10 \mathrm{~d})-400(15 \mathrm{~d})-800(13 \mathrm{~d})\end{array}$ & 62 \\
\hline & $\mathrm{J}_{7}$ & & & 0 & $\begin{array}{l}12.5(3 \mathrm{~d})-25(5 \mathrm{~d})-50(6 \mathrm{~d})-100(11 \mathrm{~d})-200 \\
(10 \mathrm{~d})-400(16 \mathrm{~d})-800(15 \mathrm{~d})\end{array}$ & 66 \\
\hline & $\mathrm{S}_{9}$ & \multirow{2}{*}{20} & \multirow{2}{*}{20} & 0 & $\begin{array}{c}12.5(24 \text { h)-25 (24 h)-50 (24 h)-100 (24 h)-200 } \\
(24 \text { h)-400 (24 h)-800 (53 d) }\end{array}$ & 59 \\
\hline & $\mathrm{S}_{10}$ & & & 1 & $\begin{array}{c}12.5(24 \mathrm{~h})-25(24 \mathrm{~h})-50 \text { (24 h)-100 (24 h)-200 } \\
(24 \mathrm{~h})-400(24 \mathrm{~h})-800 \text { (53 d) }\end{array}$ & 59 \\
\hline \multirow{5}{*}{$\begin{array}{l}\text { Effect of } \\
\text { specimen } \\
\text { height }\end{array}$} & $\mathrm{H}_{1}$ & \multirow{5}{*}{$\begin{array}{l}20,25,30,35 \\
\text { and } 40\end{array}$} & 23 & \multirow{5}{*}{1} & $12.5-25-50-100-200-400-800$ ( $24 \mathrm{~h}$ per level) & 7 \\
\hline & $\mathrm{H}_{2}$ & & 20 & & $\begin{array}{c}12.5(24 \mathrm{~h})-25(24 \mathrm{~h})-50(24 \mathrm{~h})-100(80 \mathrm{~h})-200 \\
(41 \mathrm{~h})-400(60 \mathrm{~h})-800(63 \mathrm{~h})\end{array}$ & 13 \\
\hline & $\mathrm{H}_{3}$ & & \multirow{3}{*}{23} & & $\begin{array}{c}12.5(24 \mathrm{~h})-25(24 \mathrm{~h})-50(24 \mathrm{~h})-100(46 \mathrm{~h})-200 \\
(87 \mathrm{~h})-400(93 \mathrm{~h})-800(81 \mathrm{~h})\end{array}$ & 15.8 \\
\hline & $\mathrm{H}_{4}$ & & & & $\begin{array}{c}12.5(24 \text { h)-25 (38 h)-50 (61 h)-100 (80 h)-200 } \\
(44 \text { h)-400 (96 h)-800 (96 h) }\end{array}$ & 18.3 \\
\hline & $\mathrm{H}_{5}$ & & & & $\begin{array}{c}12.5(24 \mathrm{~h})-25(85 \mathrm{~h})-50 \text { (71 h)-100 (80 h)-200 } \\
(118 \mathrm{~h})-400(43 \mathrm{~h})-800(43 \mathrm{~h})\end{array}$ & 19.3 \\
\hline
\end{tabular}

\section{Results and Discussion}

\subsection{Effect of Test Temperature on Consolidation of Peat Soil}

Low Load

After the load was loaded for $24 \mathrm{~h}$, the data were collected, and the ambient temperature was measured using a HB6801 thermometer produced by CHINA HBO INSTRYMENT (Leqing, Zhejiang). The results are shown in Figure 2.

At the low-load level, small fluctuations in the ambient temperature had a significant impact on the consolidation rate of the peat soil. The higher the temperature was, the faster the consolidation rate was, as shown in Figure 2. For example, at the load of $12.5 \mathrm{kPa}$, when the ambient temperature increased by $1.7^{\circ} \mathrm{C}$, the consolidation rate increased from $1 \times 10^{-3}$ to $1 \times 10^{-2} \mathrm{~mm} / \mathrm{h}$, where there was a ten-fold increase in the consolidation rate. At the load of $25 \mathrm{kPa}$, the temperature rose by $1.95^{\circ} \mathrm{C}$, with an eight-fold increase being observed in the consolidation rate. Secondly, the effect of temperature on the consolidation deformation of peat soil increased with an increase in the organic matter content. Comparing the deformation rate, i.e., the broken lines of $\mathrm{T}_{1}$ and $\mathrm{T}_{2}$ in Figure 2, it can be seen that the correlation between the deformation rate and the temperature of $\mathrm{T}_{2}$ (low organic peat soil) is weaker than that of $\mathrm{T}_{1}$ (highly organic peat soil), indicating that when the organic matter content is higher, the influence of the temperature is more obvious. 


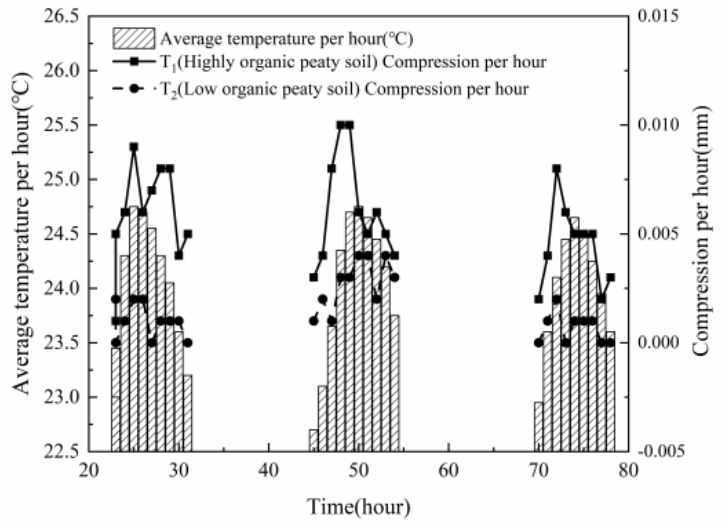

(a)

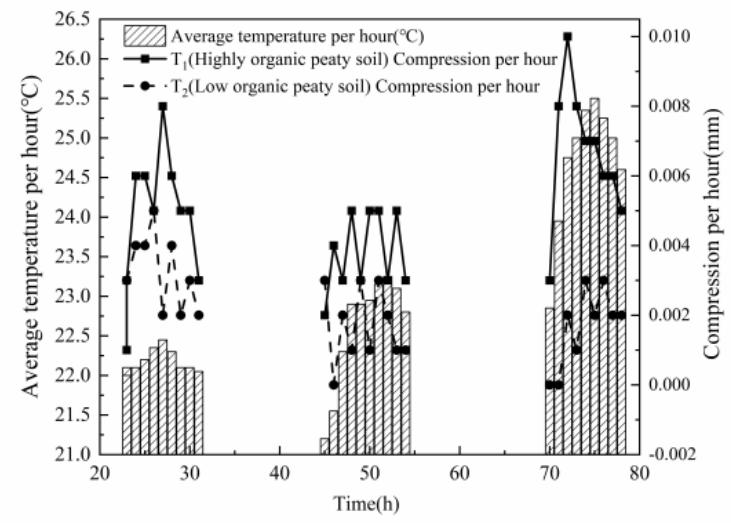

(b)

Figure 2. Temperature effect at low load: (a) $12.5 \mathrm{kPa}$; (b) $25 \mathrm{kPa}$.

\section{High Load}

The influence of ambient temperature fluctuation on the consolidation of peat soil under high pressure $(800 \mathrm{kPa})$ was analyzed by prolonging the loading time. The deformation and temperature data for high (daytime) and low temperatures (nighttime) were recorded continuously during the test, as shown in Figure 3.

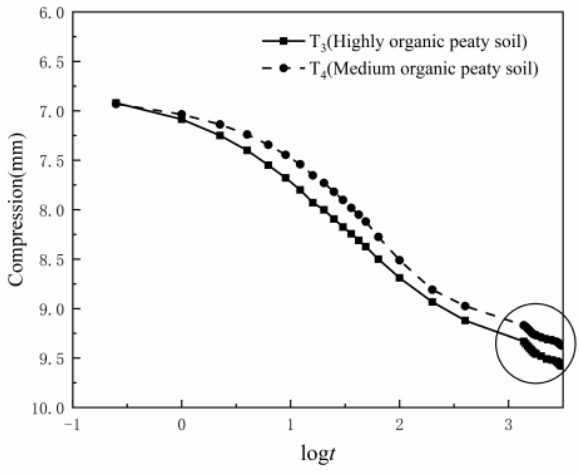

(a)

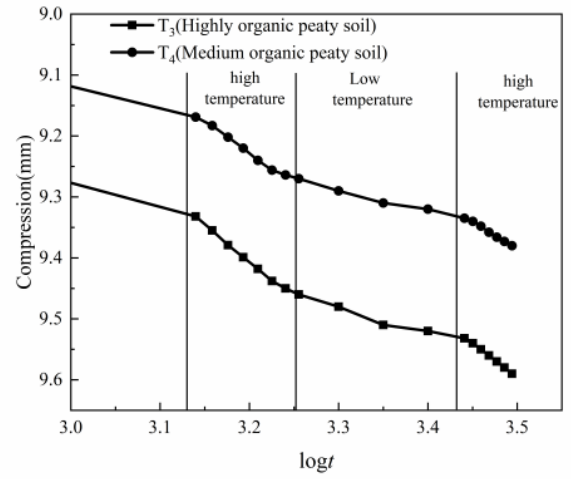

(b)

Figure 3. Temperature effect at high load: (a) consolidation curve at $800 \mathrm{kPa}$; (b) partial curve of (a). (The unit of $t$ is $\mathrm{min}$ ).

Figure 3 displays the significant effect of ambient temperature fluctuation on the consolidation rate of peat soil at high-load levels. Taking $\mathrm{T}_{3}$ as an example, the average daytime temperature was $27^{\circ} \mathrm{C}$, which was accompanied by an average consolidation rate of $1.8 \times 10^{-2} \mathrm{~mm} / \mathrm{h}$. As the nighttime temperature dropped to $22^{\circ} \mathrm{C}$, the average consolidation rate was $4 \times 10^{-3} \mathrm{~mm} / \mathrm{h}$. With a temperature rise to $26^{\circ} \mathrm{C}$ the next day, the consolidation rate of the soil sample rose to $9.3 \times 10^{-3} \mathrm{~mm} / \mathrm{h}$. This dynamic pattern shows that the temperature differences between day and night can cause conspicuous changes in the consolidation rate. As shown in Figure 3, by comparing the data for $\mathrm{T}_{3}$ and $\mathrm{T}_{4}$, the consolidation rate of peat with a high content of organic matter fluctuates more due to temperature than peat with a low content of organic matter does. This shows that the effect of temperature on the consolidation rate of peat soil is still positively correlated with the organic matter content under a high load.

Fluctuations in the ambient temperature have a direct impact on the consolidation rate of peat soil. Therefore, when conducting an indoor test on peat soil, controlling the ambient temperature is very important to ensure the accuracy of the test data. 


\section{Effect of thymol}

Previous studies have shown that there is abundant plant debris in peat soil [33], that is largely composed of lignin, cellulose, and other macromolecular organic compounds. Macromolecular organics form monosaccharides $\left(\mathrm{C}_{6} \mathrm{H}_{12} \mathrm{O}_{6}\right)$ through the action of enzymes, which then escape because of the generation of $\mathrm{CO}_{2}$ that is caused by microbial activity [34-36]. Equation (1) shows the reaction equation under proper ventilation, whereas Equations (2) and (3) are the reaction equations under poor ventilation conditions. The escape of $\mathrm{CO}_{2}$ leads to a decrease in the total organic matter and a change in the loss on ignition. Therefore, loss on ignition characterizes the decomposition of organic matter from a macro perspective.

$$
\begin{gathered}
\mathrm{C}_{6} \mathrm{H}_{12} \mathrm{O}_{6} \stackrel{\text { Microorganism }}{\longrightarrow} \mathrm{CO}_{2} \uparrow+\mathrm{H}_{2} \mathrm{O}+\text { Energy } \\
\mathrm{C}_{6} \mathrm{H}_{12} \mathrm{O}_{6} \rightarrow \mathrm{CH}_{3} \mathrm{CH}_{2} \mathrm{CH}_{2} \mathrm{COOH}+\mathrm{CO}_{2} \uparrow+\mathrm{H}_{2} \uparrow \\
\mathrm{CO}_{2}+\mathrm{H}_{2} \rightarrow \mathrm{CH}_{4} \uparrow+\mathrm{H}_{2} \mathrm{O}
\end{gathered}
$$

Through chemical analysis, Berg and Mcclaugherty [37] found that due to the activity of soil microorganisms, macromolecular organics were mineralized, and the soil gradually released nitrogen from the organic matter in the form of the ammonium ion $\left(\mathrm{NH}^{4+}\right)[38,39]$. This transformation process is shown in Figure 4 [40]. Broadbent and Nakashima [41] verified the "flow" process of nitrogen after the death of barley plants using the isotope marking process. They determined that the annual mineralization rate of nitrogen was $6.3-7.4 \%$. At present, the characterization of the decomposition degree of organic matter based on the nitrogen content has been widely used in agriculture. For example, Avnimelech et al. [42] examined the decomposition process of lake sediments by measuring the inorganic nitrogen content as well as other indicators. Davis et al. [43] analyzed the decomposition process of mangrove leaves by measuring the inorganic nitrogen content. Characterizing the decomposition degree of organic matter from a micro perspective using the total nitrogen content (TN) is therefore feasible, i.e., the decomposition degree of plants increases with an increase in the TN [44,45].

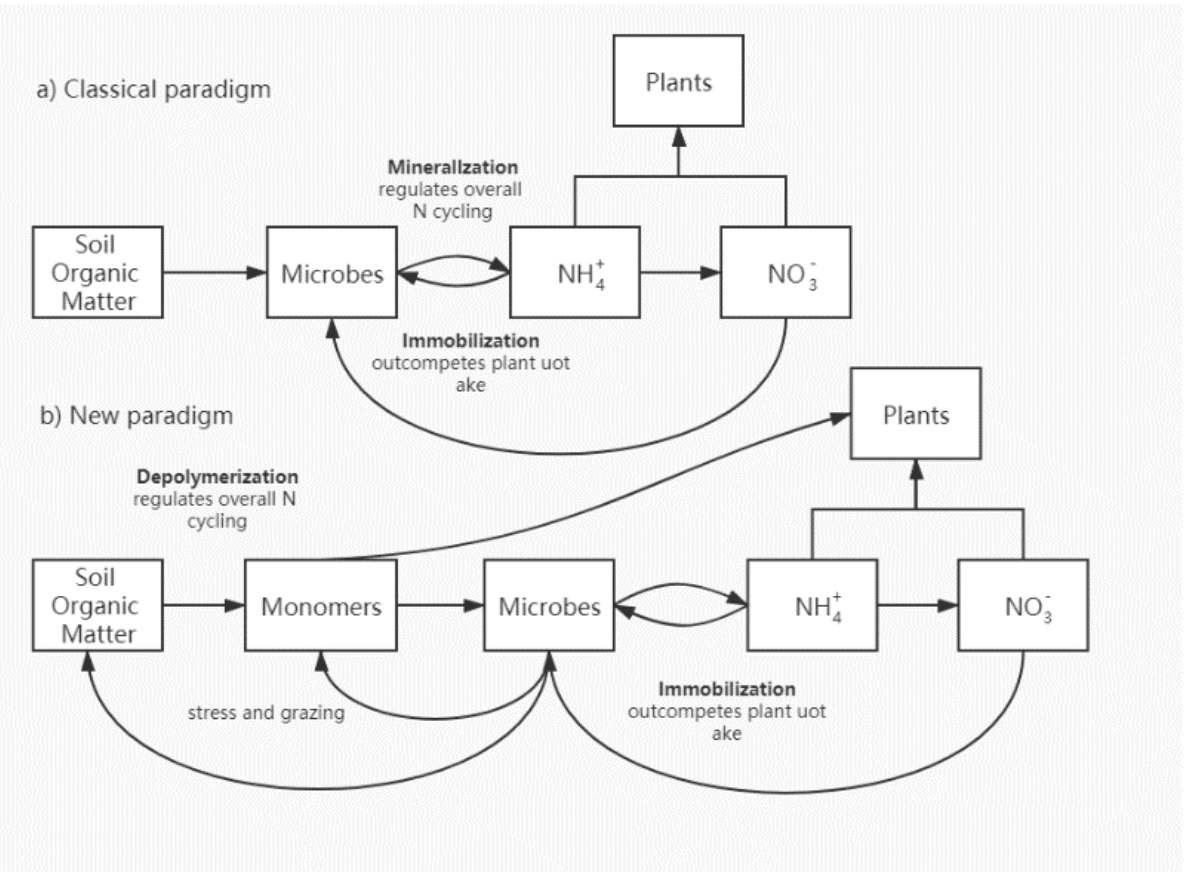

Figure 4. Two patterns of nitrogen cycling.

Thymol solution was used to control microbial reproduction and to reduce biological oxidation in peat soil test. During the analysis, the TN content and burnout were used to characterize the degree of organic matter bio-oxidation; the test results are shown in Figure 5. 


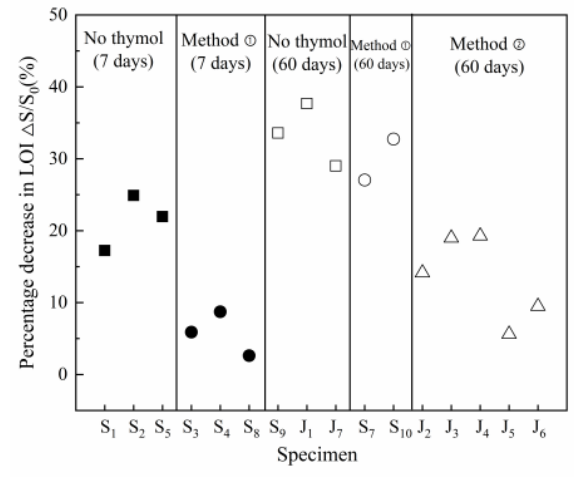

(a)

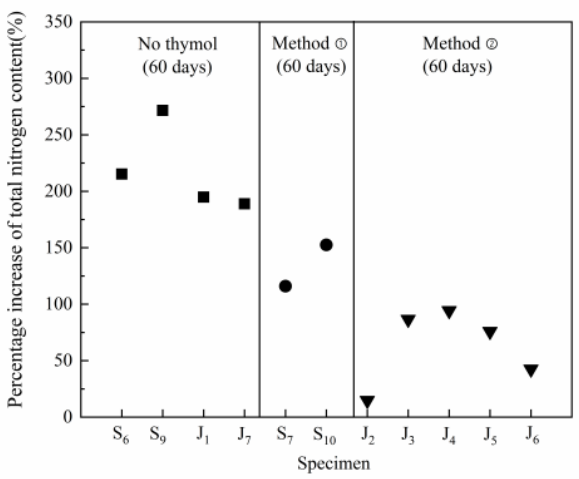

(b)

Figure 5. Percentage change in LOI and TN content. (a) Percentage decrease in LOI (b) Percentage increase in TN content. (Note: Method (1) is spraying thymol solution, method (2) is immersing in thymol solution).

Figure 5 a shows the percentage of loss on ignition before and after the test. The TN content was tested using a JR-600M soil nutrient rapid tester produced by CHINA JIRU YIQI (Weifang, Shandong), and the percent increase is shown in Figure $5 b$. The reduction of LOI and the increase in TN in the test group with the thymol solution were smaller, which shows that the sample that had been soaked with thymol solution effectively inhibited the decomposition of organic matter during consolidation. For a test lasting 7 days, spraying the thymol solution (method (1) is effective. For the 60-day test, the effect of immersing the sample in a thymol solution (Method (2) is more obvious, which may be because the spray method only works on the surface of the soil sample and because the inhibitory effect only lasts for a short time.

The filter paper on the surface of the soil sample without thymol (Figure 6) exhibited a brown substance after the test. This brown substance was the organic high-molecular compound (humus) that was formed in the humification process in peat soil [18]. The filter paper on the samples treated that had been with thymol remained white, verifying that the thymol solution inhibited the biological organic oxidation.

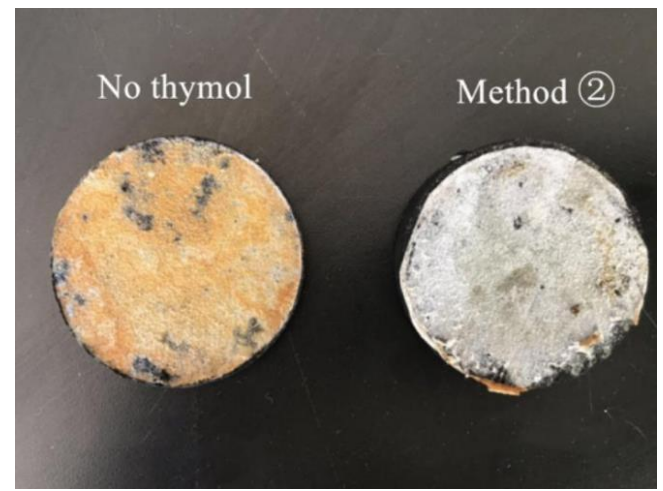

Figure 6. Post-test samples.

\section{Effect of Specimen Height}

The specimen height had a noticeable influence on the peat soil consolidation. The standard presently stipulates one-dimensional consolidation sample dimensions of $61.8 \mathrm{~mm}$ in diameter and $20 \mathrm{~mm}$ in height. Consolidation tests were conducted according to JTG 3430-2020 [32] on peat samples with diameters of $61.8 \mathrm{~mm}$ and heights of 20, 25, 30, 35, and $40 \mathrm{~mm}$. The strain of the peat soil samples with different heights were compared (Figure 7), and the optimum sample height was explored. 


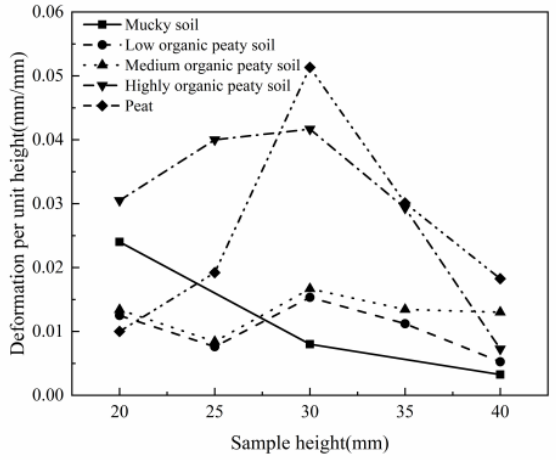

(a)

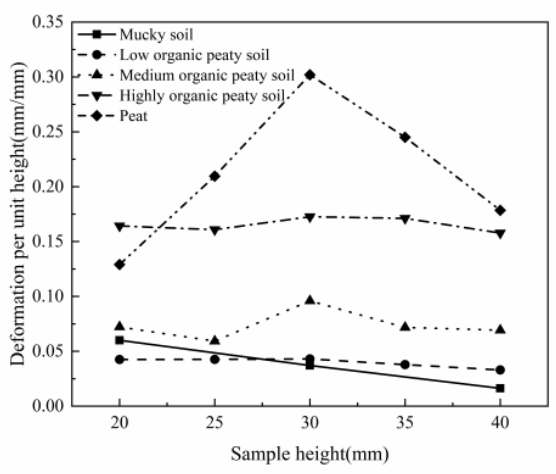

(c)

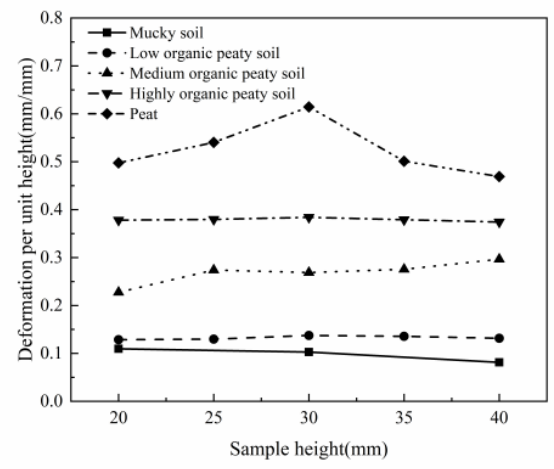

(e)

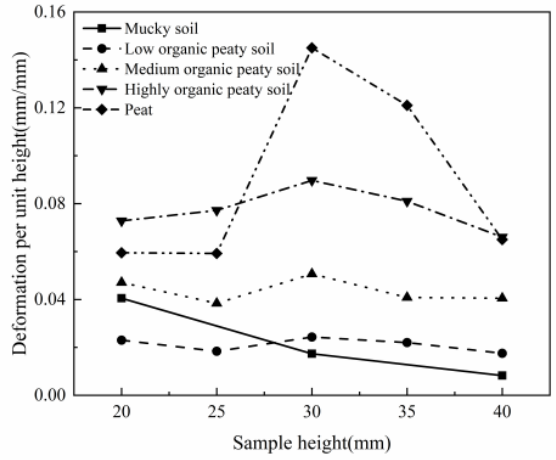

(b)

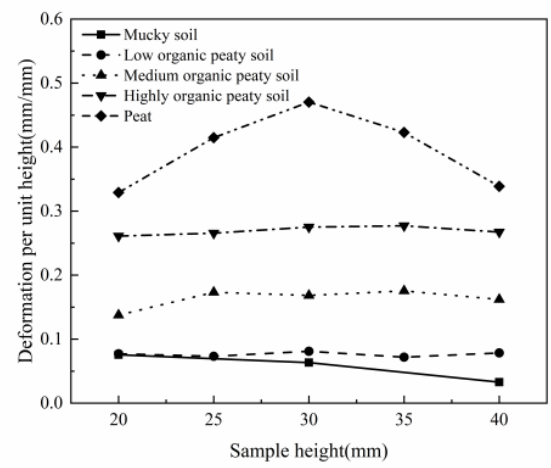

(d)

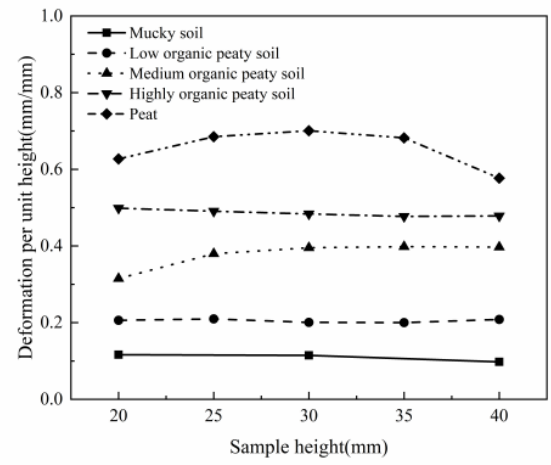

(f)

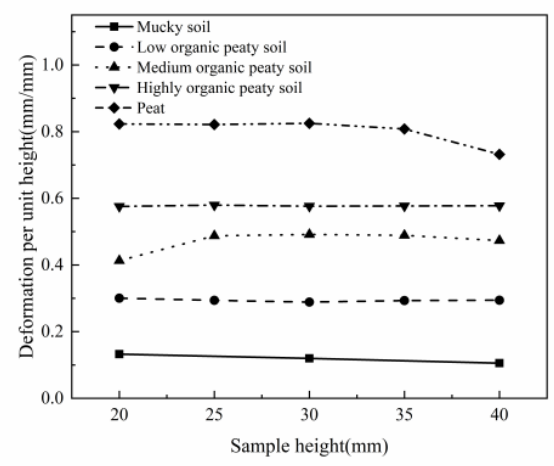

(g)

Figure 7. Strain of specimens at different heights. (a) $12.5 \mathrm{kPa}$, (b) $25 \mathrm{kPa}$, (c) $50 \mathrm{kPa}$, (d) $100 \mathrm{kPa}$, (e) $200 \mathrm{kPa}$, (f) $400 \mathrm{kPa},($ g) $800 \mathrm{kPa}$. 
The influence of sample height on the consolidation strain of mucky soil and peat was significantly different at the same load level, as shown in Figure 7. The strain of the mucky soil sample was the highest when the sample height was $20 \mathrm{~mm}$, which decreased gradually when the sample height increased, which findings for Tianjin blow-fill soil [46]. The strain of peat soil first increases and then decreases when the sample height increases, and the strain is the largest when the height is $30 \mathrm{~mm}$. When the load is greater than $100 \mathrm{kPa}$, the strain of the peaty soil $(10 \% \leq W u \leq 60 \%)$ samples with heights from $20 \mathrm{~mm}$ to $40 \mathrm{~mm}$ is the same, but the strain of peat $(W u \geq 60 \%)$ at the height of $30 \mathrm{~mm}$ is still the largest. It can be concluded that the strain of the peat soil with a height of $30 \mathrm{~mm}$ is greater than or equal to that of peat soil of other heights. Therefore, for peat soils, specimens that are $30 \mathrm{~mm}$ in height should be used for consolidation tests.

\section{Conclusions}

This study investigated the influence of temperature, biological oxidation, and sample height on the one-dimensional consolidation characteristics of peat soil under different load levels. Based on the results, the main findings and conclusions can be summarized as follows:

(1) The small range fluctuation of ambient temperature can lead to significant changes in the peat consolidation rate, and when there is a higher amount of organic matter content, then there is a more significant the effect. In order to ensure that the one-dimensional consolidation test results can truly reflect the in situ tests, during the process of the test, especially when the loading time is long, the ambient temperature should be controlled to be the same as the in situ temperature.

(2) It has been verified that the decomposition of organic matter that is caused by environmental disturbances after soil samples are taken out of the ground can be inhibited by soaking the samples in a $1 \%$ thymol solution $t$ during the one-dimensional consolidation test.

(3) The influence of the sample height on the consolidation strain of peat soil is different from that of mucky soil. The strain of peat soil at $30 \mathrm{~mm}$ height is greater than or equal to that of samples of other heights, while the strain of mucky soil with a sample height of $20 \mathrm{~mm}$ is the largest. Therefore, the use of a sample with a height of $30 \mathrm{~mm}$ is suggested when conducting a one-dimensional consolidation test on peat samples.

The TN was used to characterize changes in the organic matter content in peat soil in this study. Although this method has been widely used in agronomy, this was the first application in geotechnical experiments. This provides a new method that can be used to study changes in the organic matter in peat soil and to determine its engineering characteristics; however, the standardization of its operation process needs further study. On the other hand, the solvent in the thymol solution used in this study was ethanol. During the test process the solubility will be reduced due to the volatility of ethanol, and some thymol crystals will be separated out. However, the results show that the volatilized solution still has the effect of inhibiting microbial decomposition. In order to be more conducive to environmental protection, future studies should focus on determining the optimal concentration of the thymol solution.

Author Contributions: Conceptualization, R.F.; data curation, B.P. and R.F.; formal analysis, B.P.; funding acquisition, R.F.; investigation, B.P. and R.F.; methodology, B.P. and R.F.; project administration, R.F.; resources, L.W. and Y.S.; supervision, R.F.; writing—original draft, B.P.; writing-review and editing, B.P. and R.F. All authors have read and agreed to the published version of the manuscript.

Funding: This paper was supported by The National Natural Science Foundation of China (51778048).

Institutional Review Board Statement: Not applicable.

Data Availability Statement: All of the data and models used in this study are available from the corresponding author upon request.

Conflicts of Interest: The authors declare no conflict of interest. 


\section{References}

1. Wüst, R.A.; Bustin, R.; Lavkulich, L.M. New classification systems for tropical organic-rich deposits based on studies of the Tasek Bera Basin, Malaysia. Catena 2003, 53, 133-163. [CrossRef]

2. Davis, J.H. The peat deposits of Florida, their occurrence, development and uses (FGS: Bulletin 30). Fisioter. Pesqui. 1946, 21, 337-339. [CrossRef]

3. Ma, X. Carbon Storage and Emission of Peatland in China; Beijing, China Forestry Press: Beijing, China, 2013.

4. MCPRC (Ministry of Construction of the People's Republic of China). Code for Investigation of Geotechnical Engineering; Appendix A; China Construction Industry Press: Beijing, China, 2009.

5. Mesri, G.; Ajlouni, M. Engineering Properties of Fibrous Peats. J. Geotech. Geoenvironmental Eng. 2007, 133, 850-866. [CrossRef]

6. Jorat, M.E.; Kreiter, S.; Mörz, T.; Moon, V.; De Lange, W. Strength and compressibility characteristics of peat stabilized with sand columns. Geomech. Eng. 2013, 5, 575-594. [CrossRef]

7. Acharya, M.P.; Hendry, M.T.; Martin, C.D. Quantification of the Settlement of an Embankment Constructed on Peat due to the Expulsion of Gases. Int. J. Geomech. 2017, 17, 04016088. [CrossRef]

8. Jiang, Z. Peat Soil in Dianchi Lake; Sichuan Province, Southwest Jiaotong University Press: Chengdu, China, 1994.

9. Tashiro, M.; Inagaki, M.; Asaoka, A. Prediction of and countermeasures for embankment-related settlement in ultra-soft ground containing peat. In Proceedings of the 18th International Conference on Soil Mechanics and Geotechnical Engineering, Paris, France, 2-6 September 2013.

10. MacFarlane, I.C. Some Preliminary Consolidation Tests on Peat; Internal Report (National Research Council of Canada. Division of Building Research); no. DBR-IR-318; National Research Council of Canada: Ottawa, ON, Canada, 1965. [CrossRef]

11. Lytton, R. Foundation engineering in difficult ground. Eng. Geol. 1981, 17, 79-80. [CrossRef]

12. Fox, P.J.; Edil, T.B. Effects of stress and temperature on secondary compression of peat. Can. Geotech. J. 1996, 33, 405-415. [CrossRef]

13. Mesri, G.; Stark, T.D.; Ajlouni, M.A.; Chen, C.S. Secondary Compression of Peat with or without Surcharging. J. Geotech Geoenvironmental Eng. 1997, 123, 411-421. [CrossRef]

14. Madaschi, A.; Gajo, A. One-dimensional response of peaty soils subjected to a wide range of oedometric conditions. Geotechnique 2015, 65, 274-286. [CrossRef]

15. Mesri, G. Time-and stress-compressibility interrelationship. J. Geotech. Geoenvironmental Eng. 1977, 103, 417-430. [CrossRef]

16. Acharya, M.P.; Hendry, M.T.; Martin, C.D. Creep behaviour of intact and remoulded fibrous peat. Acta Geotechnica. 2017, 13, 1-19. [CrossRef]

17. Hanson, J.L.; Edil, T.B.; Fox, P.J. Stress-Temperature Effects on Peat Compression. Geotech. Spec. Publ. 2001, 331-345. [CrossRef]

18. Dhowian, A.; Edil, T. Consolidation Behavior of Peats. Geotech. Test. J. 1980, 3, 10. [CrossRef]

19. Lozet, J.; Mathieu, C. Dictionary of Soil Science. Soil. Sci. 1993, 155, 73. [CrossRef]

20. Prokopovich, N.P. Subsidence of Peat in California and Florida. Environ. Eng. Geosci. 1985, xxii, 395-420. [CrossRef]

21. Laiho, R. Decomposition in peatlands: Reconciling seemingly contrasting results on the impacts of lowered water levels. Soil Biol. Biochem. 2006, 38, 2011-2024. [CrossRef]

22. Philben, M.; Kaiser, K.; Benner, R. Does oxygen exposure time control the extent of organic matter decomposition in peatlands? J. Geophys. Res. Biogeosciences 2014, 119, 897-909. [CrossRef]

23. Klarić, M.E.; Kosalec, I.; Mastelić, J.; Piecková, E.; Pepeljnak, S. Antifungal activity of thyme (Thymus vulgaris L.) essential oil and thymol against moulds from damp dwellings. Lett. Appl. Microbiol. 2007, 44, 36-42. [CrossRef]

24. O'Kelly, B.C.; Zhang, L. Consolidated-Drained Triaxial Compression Testing of Peat. Geotech. Test. J. 2013, 36, 310-321. [CrossRef]

25. Long, M.; Boylan, N. Predictions of settlement in peat soils. Q. J. Eng. Geol. Hydrogeol. 2013, 46, 303-322. [CrossRef]

26. Carlsten, P. Geotechnical properties of peat. In State of the Art, 2nd ed.; Baltic Conference on Soil Mechanics and Foundation Engineering: Tallinn, Estonia, 1988.

27. Lefebvre, G.; Langlois, P.; Lupien, C.; Lavallée, J.-G. Laboratory testing and in situ behaviour of peat as embankment foundation. Can. Geotech. J. 1984, 21, 322-337. [CrossRef]

28. O'Kelly, B.C. Effective stress strength testing of peat. Environ. Geotech. 2015, 2, 34-44. [CrossRef]

29. Sun, J. Diabatic Heating Characteristics in the East Peripheral Area of Qinghai-Tibetan Plateau and its Climate Effect during Spring-Summer Transition Season. Ph.D. Thesis, School of Atmospheric Science, Nanjing University of Information Science \& Technology, Nanjing, China, 2011.

30. Gao, Y.B.; Zhu, H.H.; Guan-Bao, Y.E.; Chao, X.U. The investigation of the coefficient of secondary compression Ca in odometer tests. Chin. J. Geotech. Eng. 2004, 26, 5. [CrossRef]

31. Gui, Y.; Yu, Z.H.; Liu, H.M.; Cao, J.; Wang, Z.C. Secondary consolidation properties and mechanism of plateau lacustrine peaty soil. Chin. J. Geotech. Eng. 2015, 37, 1390-1398. [CrossRef]

32. RIHMT (Research Institute of Highway Ministry of Transport). Test Methods of Soils for Highway Engineering; People's Communications Press: Beijing, China, 2020.

33. Piotr, Z.; Rydelek, P.; Bakowska, A. Geo-engineering properties of Eemian peats from Radzymin (central Poland) in the light of static cone penetration and dilatometer tests. Eng. Geology 2017, 226, 290-300. [CrossRef]

34. Liu, K.; Xue, J.; Yang, M. Deformation behaviour of geotechnical materials with gas bubbles and time dependent compressible organic matter. Eng. Geol. 2016, 213, 98-106. [CrossRef] 
35. Bosch, A.; Schmidt, K.; He, J.-S.; Doerfer, C.; Scholten, T. Potential $\mathrm{CO}_{2}$ emissions from defrosting permafrost soils of the Qinghai-Tibet Plateau under different scenarios of climate change in 2050 and 2070. Catena 2017, 149, 221-231. [CrossRef]

36. Lal, R. Soil Erosion and Gaseous Emissions. Appl. Sci. 2020, 10, 2784. [CrossRef]

37. Berg, B.; Mcclaugherty, C. Plant Litter. In Decomposition, Humus Formation, Carbon Sequestration; Springer: Berlin/Heidelberg, Germany, 2020. [CrossRef]

38. Jarvis, S.C.; Stockdale, E.A.; Shepherd, M.A.; Powlson, D.S. Nitrogen Mineralization in Temperate Agricultural Soils: Processes and Measurement. Adv. Agron. 1996, 57, 187-235. [CrossRef]

39. Schimel, J.P.; Bennett, J. Nitrogen Mineralization: Challenges of A Changing Paradigm. Ecology 2004, 85, 591-602. [CrossRef]

40. De Figueiredo, C.C.; Coser, T.R.; Moreira, T.N.; Leão, T.P.; Vale, A.T.D.; Paz-Ferreiro, J. Carbon Mineralization in a Soil Amended with Sewage Sludge-Derived Biochar. Appl. Sci. 2019, 9, 4481. [CrossRef]

41. Broadbent, F.E.; Nakashima, T. Mineralization of Carbon and Nitrogen in Soil Amended with Carbon13 and Nitrogen15 Labeled Plant Material1. Soil Sci. Soc. Am. J. 1974, 38, 34-37. [CrossRef]

42. Avnimelech, Y.; McHenry, J.R.; Ross, J.D. Decomposition of organic matter in lake sediments. Environ. Sci. Technol. 1984, 18, 5-11. [CrossRef] [PubMed]

43. Davis, S.E.; Corronado-Molina, C.; Childers, D.L.; Day, J.W. Temporally Dependent C, N, and P Dynamics Associated with the Decay of Rhizophora mangle L. Leaf Litter in Oligotrophic Mangrove Wetlands of the Southern Everglades. Aquat. Bot. 2003, 75, 199-215. [CrossRef]

44. Alexander, H. Increasing Red Maple Leaf Litter Alters Decomposition Rates and Nitrogen Cycling in Historically Oak-Dominated Forests of the Eastern U.S. Ecosystems 2014, 17, 1383. [CrossRef]

45. Rabarijoely, S. A Bayesian Approach in the Evaluation of Unit Weight of Mineral and Organic Soils Based on Dilatometer Tests (DMT). Appl. Sci. 2019, 9, 3779. [CrossRef]

46. Lei, H.; He, C.; Qiu, W.; Chen, L. Experimental Research on Size Effect Upon Consolidation Propert y of Hydraulic Reclamation Soft Clay. J. Tianjin Univ. Sci. Technol. 2016, 49, 7. [CrossRef] 